\title{
Oil of Mesua ferrea L. Seed as a Promising Pharmaceutical Excipient in Lipid Based Nanoformulation
}

\author{
Tapash Chakraborty, Malay K. Das* \\ Department of Pharmaceutical Sciences, Dibrugarh University, Dibrugarh 786004, India.
}

\begin{tabular}{|c|c|}
\hline ARTICLE INFO & ABSTRACT \\
\hline Article history: & This paper reports the studies on the application of Mesua ferrea L. (nahor) seed oil as a safe pharmaceutical \\
\hline Received on: 12/11/2016 & excipient. The nahor seed oil was extracted by hot continuous percolation process using a soxhelt apparatus and \\
\hline Accepted on: 24/02/2017 & analyzed by TLC and LC-MS. The safety profile of the oil was studied by acute toxicity study in a rat model and \\
\hline Available online: $30 / 07 / 2017$ & MTT assay with mouse brain endothelial cells (bEnd.3). The compatibility of the oil with other excipients was \\
\hline $\begin{array}{l}\text { Key words: Acute toxicity, } \\
\text { Biocompatibility, Messua } \\
\text { ferrea L., Nahor seed oil, } \\
\text { NLC, Pharmaceutical } \\
\text { excipient. }\end{array}$ & $\begin{array}{l}\text { other USP grade oils. The acute toxicity study and MTT assay suggest the safe use of the nahor oil at the } \\
\text { cellular level in the living system. DSC and FT-IR study confirm the compatibility of the oil with the general } \\
\text { components of the lipid nanoparticles. This work provides a new dimension to } M \text {. ferrea L. seed oil for its safe } \\
\text { use in the pharmaceutical formulation. }\end{array}$ \\
\hline
\end{tabular}

\section{INTRODUCTION}

Pharmaceutical excipients play the greatest role in modern pharmaceutical dosage forms. The importance of excipients has been neglected by the pharmaceutical companies, as we can see almost no or very little money and men power has been utilized to discover new excipients or to determine the safety profile of the existing excipients (Baldrick, 2000). Development of new excipients or finding one in nature gets less importance and funding than an active pharmaceutical ingredient (API) (Bahadur et al., 2014). The formulation development strategies reveal that the same API can act better in the formulations developed with different excipients. Hence, finding a new excipient can lead to the development of stable and efficient pharmaceutical dosage format low cost (Chaudhari and Patil, 2012). Pharmaceutical excipients act as a vehicle to carry the API to the desired site of drug action in the desired dosage form. These vehicles can be either solid or different types of liquids. Fixed oils

\footnotetext{
* Corresponding Author

Malay K Das, Department of Pharmaceutical Sciences, Dibrugarh University, Dibrugarh 786004 India. Email: mkdps @ dibru.ac.in
}

are the most important group of non-aqueous pharmaceutical excipients. Detailed specifications for fixed oils have been provided in the USP. These specifications clearly indicate that the fixed oils from vegetable origin are liquid at room temperature, easily metabolized, free from rancidification and stable. The USP has specified standard iodine value, saponification value and free fatty acid content of these oils. A chart of these limits of different physicochemical properties of different USP specified oils has been given in Table 1 . These oils are used particularly as vehicles for certain hormone and vitamin preparations. The labels of these formulations must state the name of the oils used in it, so that patients can avoid these formulations if he or she has sensitivity to these oils (Virendrakumar et al., 2015). The vegetable oils used in pharmaceutical formulations have a similar type of composition except for castor oil, which contains a unique fatty acid, the Ricinoleic acid in higher quantities (about 86-90\%). Other oils generally containOleic acid, Linolenic acid, Linoleic acid, Myristic acid, Palmitic acid, and Stearic acid, in different quantities (Rabasco Alvarez and González Rodríguez 2000; Tunaru et al., 2012). These components have been separated successfully and are used in pharmaceutical formulations either in crude form or after chemical modification along with the oil itself. 
Table 1: Limits of different physicochemical properties of some USP specified oils (NA= Not available).

\begin{tabular}{|c|c|c|c|c|c|c|}
\hline Properties & Sesame Oil & Corn Oil & Cottonseed Oil & Peanut Oil & Soybean Oil & Castor oil \\
\hline Specific gravity & $0.916-0.921$ & $0.914-0.921$ & $0.915-0.921$ & $0.912-0.920$ & $0.916-0.922$ & $0.957-0.961$ \\
\hline Iodine value & 103-116 & $102-130$ & $109-120$ & $84-100$ & $120-141$ & 83-88 \\
\hline Saponification value & $188-195$ & $187-193$ & NA & $185-195$ & $180-200$ & $176-182$ \\
\hline Unsaponifiable matter & Not $>1.5 \%$. & Not $>1.5 \%$. & NA & Not $>1.5 \%$. & Not $>1.0 \%$. & NA \\
\hline Heavy metals & $0.001 \%$ & $0.001 \%$ & $0.001 \%$. & $0.001 \%$ & $0.001 \%$ & NA \\
\hline
\end{tabular}

Table 2: A comparative list of components of different oils used in pharmaceutical formulations (from literature; CA= Component absent) (Lakshminarayana et al., 1984; Were et al., 2006; Labuschagne and Hugo 2010; Shahzad et al., 2011).

\begin{tabular}{ccccccccc}
\hline & \multicolumn{6}{c}{ Fatty acids (in \%) } \\
\cline { 2 - 8 } & $\begin{array}{c}\text { Myristic } \\
\text { acid }\end{array}$ & $\begin{array}{c}\text { Palmitic } \\
\text { acid }\end{array}$ & $\begin{array}{c}\text { Stearic } \\
\text { acid }\end{array}$ & Oleic acid & $\begin{array}{c}\text { Linolenic } \\
\text { acid }\end{array}$ & $\begin{array}{c}\text { Linoleic } \\
\text { acid }\end{array}$ & Arachidic acid & Special fatty acid \\
\hline Castor Seed Oil & CA & 2.0 & 1.0 & 7.0 & CA & 5.0 & CA & Ricinoleic (86-90) \\
Cotton Seed Oil & 0.4 & 20 & 2.0 & 35 & CA & 42 & CA & CA \\
Groundnut Oil (Penut Oil) & CA & $6.0-9.0$ & $3.0-6.0$ & $52.0-60.0$ & CA & $13.0-27.0$ & $2.0-4.0$ & Lignoceric 1-3 Behenic acid 1-3 \\
Sesame Oil (Til Oil) & CA & $7.0-9.0$ & $4.0-5.0$ & $40.0-50.0$ & CA & $35.0-45.0$ & $0.4-1.0$ & CA \\
\hline
\end{tabular}

A comparative list of the composition based on the literature of those USP specified oils has been given in Table 2.

The plant Mesua ferrea L. (Famaily: Clusiaceae) is commonly known as Nahorin North-East India. It is readily available in wild in almost all the districts of north and northeastern states of India and Bangladesh (Arunachalam et al., 2003). The aerial parts of the plant are used in traditional medicine for several indications such as rheumatism(Jalalpure et al., 2011), cough, sore throat, fever, vomiting, dysentery, itch from the ancient times. Flower extracts are proven to show the abortifacient property. The uses of $M$. ferrea L. seed oil is of nonedible type and are used for poulticing wounds, treating itch, skin eruptions and dandruff (Chanda et al., 2013). In Java, a decoction of the flowers is drunk by women after childbirth. The stamens of $M$. ferrea L. is used with other herbal ingredients like seeds of Wrightia tinctoria, and the shells of pearl oysters (Pinctada margaritifera) to formulate Qurs-e-Habis, which is a traditional medicine used as a hemostatic, antidysenteric and antidiarrhoeal(Rasheed and Gupta 2010).

The acute toxicity of the methanolic extract of the leaf of M. ferrea L. was determined by Udayabhanu et al., in Swiss albino mice model. They concluded that the oral administration of the methanolic leaf extract to mice does not cause any acute adverse effect or death to the animal model (Udayabhanu et al., 2014).

The oils mostly used for pharmaceutical formulation purposes are edible and have an ever increasing demand with the growing world population and hence has a higher price tag. Peanut oil, corn oil, cottonseed oil, and sesame oil are some of the USP prescribed oils. Hence, finding some other oil from nature, which can be used as a pharmaceutical excipient having similar properties and safety profile with that of the edible oils, is very much important. It may reduce the use of edible oils in pharmaceuticals and also reduce the formulation cost. The present study evaluates the oil of $M$. ferrea L. seed for its potential application in pharmaceutical nanoformulation. The acute toxicity profile of the oil was determined in a rat model as per OECD guidelines. The chemical and biological compatibility of the oil were also studied in the form of nanostructures lipid carriers to establish the oil as a valuable and safe pharmaceutical excipient.

\section{MATERIALS AND METHODS}

\section{Materials}

Petroleum ether (B.P.: $60-80{ }^{\circ} \mathrm{C}$ ), Stearic acid, Palmitic acid, Cholesterol, Silica gel Gwere purchased from HiMedia, Mumbai, India. Ethanol was purchased from Merck Millipore, Mumbai, India. Vitamin E and Phosphoric acid were purchased from Sigma Aldrich, Bengaluru, India. All the other chemicals and reagents used were of analytical grade. The nahor fruits were collected from $M$. ferrea L. plants in the Dibrugarh University campus. The herbal sample was authenticated by Botanical Survey of India (BSI), Eastern Regional Centre, Shillong, Meghalaya, India.

\section{Methods}

\section{Extraction of M. ferreaL. seed oil}

The collected nahor fruits were shade dried for 7 days. Seed kernels were removed from the dried fruit shells. The kernels were sun dried for another 3-4 days. Kernels were then cut into small chips and again sun dried until it becomes non sticky. The dried seed kernels were ground coarsely (\# 30) and stored in air tight containers for future use.

The powdered samples were extracted with continuous hot percolation process at $80{ }^{\circ} \mathrm{C}$ using petroleum ether (B.P. $60-$ $80{ }^{\circ} \mathrm{C}$ ) in a soxhlet apparatus (Borosil ${ }^{\circledR}$, Gujarat, India) for 24 hours. After extraction, petroleum ether was removed from theoil by rotary vacuum evaporator $\left(\mathrm{IKA}^{\circledR} \mathrm{RV} 10\right.$ digital, IKA, Germany) with $100 \mathrm{~m}$ Bar pressures at $80{ }^{\circ} \mathrm{C}$ until viscous oil was obtained.

The oil was then placed in a hot air oven at $45{ }^{\circ} \mathrm{C}$ until complete disappearance of the smell of petroleum ether. Finally, the oil was stored in amber colored glass bottle at $4-8{ }^{\circ} \mathrm{C}$ for further analysis. 
Physical and chemical characterization of $M$. ferrea $L$. seed oil

The yield $(\%)$ was calculated from the weight of powder taken for extraction and the weight of the oil obtained (Nkafamiya et al., 2010). Sudan IV test and translucence Lipid Test was performed to confirm that the extracted material was a lipid. The specific gravity of the extracted oil was determined at room temperature with a Pycnometer. The density of the extracted oil was also calculated using the pycnometer data. The moisture content (\%)of the oil was determined by drying the oil at $80{ }^{\circ} \mathrm{C}$ in a hot air oven until it achieved a constant weight. The acid value, saponification value, un-saponification matter in the oil, peroxide value, iodine value was determined by the standard methods (Hilditch 1946; de Peña et al., 1992; Nzikou et al., 2010; Mahale and Goswami-Giri 2011). The amount of vitamin $E$ and cholesterol was also determined by standard methods (Rutkowski and Grzegorczyk 2007; Daksha et al., 2010). The chemical stability of the oil was checked after 6 months of storage at room temperature.

\section{Composition of $M$. ferrea L. seed oil}

The separation and identification of the components of the $M$. ferrea L. Oil was performed by analytical TLC method using some probable standard components along with the test sample (Asha 2015). TLC plates were prepared by pouring thick slurry of silica gel $\mathrm{G}$ on a glass plate $(15 \mathrm{~cm} \times 20 \mathrm{~cm})$ followed by activation of the plate by heating at $120^{\circ} \mathrm{C}$ for 30 minutes. Standard components (oleic acid, linoleic acid, linolenic acid, stearic acid, palmitic acid, myristic acid, cholesterol, vitamin E) and the sample were dissolved in petroleum ether and the spot was applied on the TLC plate with capillary tubes (Sasidharan et al., 2011). The spots were air dried and TLC was run with ternary mixture of n-Hexane, diethyl ether, acetic acid (70:30:1) as the mobile phase. The diluted sulphuric acid $\left(\mathrm{H}_{2} \mathrm{SO}_{4}: \mathrm{H}_{2} \mathrm{O}=1: 9\right)$ was sprayed as detecting reagent followed by heating the plate at $110^{\circ} \mathrm{C}$ until the spots were visible (Nour et al., 2010). The composition of the eluent was finalized using different solvent systems in trial and error method. The $\mathrm{R}_{f}$ values of all the spots on the TLC plate were determined and the $\mathrm{R}_{f}$ values of the sample components were compared with those of the standards.

The quantitative fatty acid composition of $M$. ferrea $\mathrm{L}$. seed oil was studied by LC-MS (Waters ZQ-4000, Milford, Massachusetts, USA). The sample was dissolved in acetonitrile and analyzed with a reversed-phase separating column (Brownlee SPP C18 column, $2 \mathrm{~mm}$ x $10 \mathrm{~cm}$ ).Acetonitrile/ethyl acetate was used as mobile phase in a gradient manner at a flow rate of 0.4 $\mathrm{mL} / \mathrm{min}$. Components were identified manually by observing the $\mathrm{m} / \mathrm{z}$ values and the peak heights of the parent peaks in the mass spectrum (Mamoci et al., 2011).

\section{Acute toxicity study of $M$. ferrea L. seed oil}

Acute toxicity study was performed as per the Organization for Economic Cooperation and Development (OECD) guidelines 423. The Institutional Animal Ethical Committee (IAEC)of Dibrugarh University approved the experimental protocol (Approval No. IAEC/DU/120 dated 18/02/2016).

The acute toxicity study was performed using healthy young adult Wister rats of both sex, nulliparous, non-pregnant and weighing 80-150 g. Rats were randomly divided into five groups each of three rats. Identification of the rats was done by putting ink marks on the tail. The animals were kept in polypropylene cages $(55 \times 32.7 \times 19 \mathrm{~cm})$, bottom covered with sawdust in an air and temperature controlled room $\left(23 \pm 2{ }^{\circ} \mathrm{C}\right) .12 \mathrm{~h}$ of light and $12 \mathrm{~h}$ of dark cycle was maintained for each $24 \mathrm{~h}$ period with artificial lighting. Each animal cage contained an identification card. Number and weight of the animals, test substance code, route of administration, drug dose etc. were written on that cage identification card. Rats were fed with laboratory animal food pellets (Oxbow Regal Rat Food, Rhinelander, Wisconsin, USA) with water ad libitum.

Rats were fasted overnight before dosing (only food was withheld but not water). In the morning of the dosing day, animals were weighed and $M$. ferrea $\mathrm{L}$. oil was administered orally at a dose of 5,50, 300 and $2000 \mathrm{mg} / \mathrm{kg}$ of body weight using specially designed rat oral needle. The control group received double distilled water at a dose of $2000 \mathrm{mg} / \mathrm{kg}$ of body weight. At $3 \mathrm{~h}$ post administration the rats were allowed to food. The administration volume was kept at $1 \mathrm{ml} / \mathrm{kg}$ body weight of the animal. The quantity of the test substance was calculated based on the body weight of the animal on the day of treatment.

Observation of the treated and control group rats started just after dosing was completed. All the animals were observed individually each hour on the first day of dosing, 4 times daily for next 7 days, and twice daily on the remaining 6 days for a total period of 14 days. Any symptoms of ill-health or abnormal behavior (tremors, salivation, diarrhea, sleep, and coma, changes on skin and fur, eyes and mucus membrane, behavior pattern and death) were recorded as per OECD guideline no. 423.

The body weights of an individual animal of each group were recorded at $1,3,7,10$ and $14^{\text {th }}$ day of the experiment and average weight of each group was tabulated. The data were statistically analyzed by one-way analysis of variance (ANOVA, one way) using Graph Pad Prism (version 5.03) software. Significance of difference between control and test data was analyzed by Student's $t$-test.A statistical difference $\mathrm{P}>0.05$ was considered significant.

\section{Development of Nanostructured Lipid Carriers (NLCs) with M. ferrea L. seed oil}

The NLCs formulation (Table 3) was developed by modified emulsion solvent diffusion method using extracted $M$. ferrea L. seed oil as a liquid lipid along with behenyl alcohol as a solid lipid (Fan et al., 2014). Pluronic F68 was used as the surfactant. Briefly, $10 \mathrm{mg}$ of behenyl alcohol was mixed with 7.5 $\mathrm{mg}$ of $M$. ferrea L. seed oil. The lipid mixture was mixed with 2 $\mathrm{ml}$ of absolute ethanol and heated to $55^{\circ} \mathrm{C}$ in a beaker over a hot plate cum magnetic stirrer (IKA ${ }^{\circledR}$ RCT basic, IKA, Germany). The lipid mixture was added gradually into $10 \mathrm{ml}$ of $1 \% \mathrm{w} / \mathrm{v}$ Pluronic 
F68 at $55{ }^{\circ} \mathrm{C}$ with stirring at $500 \mathrm{rpm}$ for $10 \mathrm{~min}$. This mixture was then ultra-sonicated (power $100 \mathrm{~W}$, frequency $40 \mathrm{Khz}$ ) for 20 minutes at $55{ }^{\circ} \mathrm{C}$ in a bath sonicator (UCB 30, Spectra Lab, India). The formulation was then stirred on a magnetic stirreruntil complete evaporation of ethanol ( 2.5-3.0 h).Finally, the formulation was lyophilized (temperature $-80{ }^{\circ} \mathrm{C}$, pressure 0.02 m.bar)' with $5 \% \mathrm{w} / \mathrm{v}$ sorbitol using a lyophilizer (SS1-LYO, Southern Scientific Lab Instruments, Chennai, India) and stored in refrigerator for further study (Shete and Patravale 2013; Tamjidi et al., 2014).

Table 3: Formulation of NLCs.

\begin{tabular}{cccccc}
\hline Components & $\begin{array}{c}\text { Solid lipid } \\
\text { (Behenyl } \\
\text { alcohol) }\end{array}$ & $\begin{array}{c}\text { Liquid } \\
\text { lipid } \\
\text { (Nahor } \\
\text { seed oil) }\end{array}$ & $\begin{array}{c}\text { Surfactant } \\
\text { (Pluronic } \\
\text { F68) }\end{array}$ & $\begin{array}{c}\text { Organic } \\
\text { Phase } \\
\text { (Ethanol) }\end{array}$ & $\begin{array}{c}\text { Aqueous } \\
\text { Phase } \\
\text { (Water) }\end{array}$ \\
\hline Quantity & $10 \mathrm{mg}$ & $7.5 \mathrm{mg}$ & $100 \mathrm{mg}$ & $2 \mathrm{ml}$ & $10 \mathrm{ml}$ \\
\hline
\end{tabular}

The average particle size, polydispersity index (PDI) and zeta potential of the NLCs were determined using particle size analyzer (Zetasizer Nano ZS90, Malvern, UK). The particle size of the NLC was measured at a $90^{\circ}$ scattering angle using Dynamic Light Scattering. The zeta potential of the NLC formulation was measured by using Laser Doppler Micro-electrophoresis. A 1:100 dilution of the sample was made using double-distilled water before the measurements (Tsai et al., 2012).

\section{Compatibility study of the M. ferrea L. oil with other NLC components}

To determine any incompatibility between the components of the NLC formulation, Differential scanning calorimetry (DSC) and Fourier transform infrared spectroscopy (FT-IR) study of the individual components, physical mixture of the formulation components and the lyophilized formulation were done (Tita et al., 2014). The sample was simply placed over the sample plate of the FT-IR instrument (Bruker, ALPHA, Billerica, Massachusetts, USA) and the covering probe was placed over the sample. IR spectrum was obtained over a wave number region of 400 to $4000 \mathrm{~cm}^{-1}$ (wavelength of 2.5 to $25 \mu$ ).

DSC curves were recorded with a Differential Scanning Calorimeter (PerkinElmer, DSC 4000, Waltham, Massachusetts, USA) in a closed aluminum crucible.5-10 $\mathrm{mg}$ of the sample powder was placed in the alumina crucible and heated between 30 - $445^{\circ} \mathrm{C}$ with nitrogen flow at $50 \mathrm{~mL} / \mathrm{min}$ with a heating rate of $10^{\circ} \mathrm{C} / \mathrm{min}$. The curves were analyzed visually with references from the literatures.

\section{Cytotoxicity study of NLC formulation}

Cytotoxicity study of the NLC formulation was done by MTT assay on mouse (Mus musculus) brain endothelial cell line (bEnd.3; ATCC, USA). For the MTT assay, 5000cells/well were seeded in 96 well plates with DMEM mixed with fetal bovine serum $(10 \% \mathrm{v} / \mathrm{v})$, Glutamax ${ }^{\mathrm{TM}}(1 \%)$, penicillin $\mathrm{G}(100 \mathrm{U} / \mathrm{ml})$ and streptomycin $(100 \mathrm{mg} / \mathrm{ml})$ and placed inside a $\mathrm{CO}_{2}$ incubator $(5 \%$ $\mathrm{CO}_{2}$ ) at $37^{\circ} \mathrm{C}$. On the confluent growth of the cells, plates were treated with four concentrations between $1-1000 \mu \mathrm{g} / \mathrm{ml}$ of the reconstituted lyophilized NLC formulation in distilled water for 3 time points at $24 \mathrm{~h}, 48 \mathrm{~h}$ and $72 \mathrm{~h}$. The positive and negative control was dimethyl sulphoxide (DMSO, $10 \% \mathrm{v} / \mathrm{v}$ ) and blank media, respectively. After specific time points of the treatment, plates were collected and cells were treated with $120 \mu \mathrm{L}$ of 3-(4,5dimethylthiazol-2-yl)-2,5-diphenyltetrazolium bromide (MTT, EMD Bioscience Inc, CA, USA) and incubated for $3 \mathrm{~h}$. Living cells converts the MTT dye to its insoluble form, formazan, with the help of NAD(P)H-dependent cellular oxido-reductase enzyme. The higher is the number of living cells, the higher is the formation of formazan. The media were aspirated and $200 \mu \mathrm{L}$ of DMSO was added to each well, plates were incubated for $10 \mathrm{~min}$ with shaking and absorbance was read at $570 \mathrm{~nm}$ with a reference at $650 \mathrm{~nm}$ using a micro plate reader (FLUOstar Omega, BMG LABTECH, UK). Higher reading gives a direct indication of the presence of higher number of living cells. The data was then analyzed with MS Office Excel by comparing the readings of the test samples with the negative and positive control (van Meerloo et al., 2011; Angius and Floris 2015).

\section{RESULTS AND DISCUSSION}

The vegetable oils are mainly used as formulation vehicle in the drug delivery systems. They are inert in nature with some exceptions e. $\mathrm{g}$ castor oil is used as laxative. The vegetable oil based formulations are mainly for oral administration, but some oil formulations are injected intramuscularly for giving a controlled release property. Different parts of $M$. ferrea L. plant have been used traditionally in fever, cold, asthma, inflammation, septic conditions. It has been utilized as a diuretic, antipyretic, carminative, expectorant, cardio tonic etc. (Rai et al., 2000). It has been tested for various medicinal benefits for its antioxidant and hepato-protective property (Makchuchi et al., 2010), antiulcer activity (Gopalakrishnan, 1980), sore throat (Bandaranayake et al., 1975), cough and asthma (Bala and Seshadri, 1971). The physicochemical properties and composition of some vegetable oils mentioned in USP are given in Table 1 and Table 2, respectively.

\section{Extraction and physicochemical characterization of extracted} oil

The solvent extraction of $M$. ferrea $\mathrm{L}$. seed yielded about $68.98 \%$ oil. Identification tests confirm that the extracted material is a lipid. The physical and chemical properties of the extracted oil were evaluated by standard methods (Hilditch 1946; Nzikou et al., 2010; Rutkowski and Grzegorczyk 2007; Daksha et al., 2010) and are presented in the Table 4 and Table 5.

Physicochemical properties of the extracted M. ferrea L. oil are very similar to the other vegetable oils mentioned in USP (Table 1). Vegetable oils have a tendency to undergo oxidation on standing by environmental oxygen, metal ions, free radicals etc., which is known as rancidity. This leads to a higher acid value of the oils. But $M$. ferrea L. oil contains a higher amount of 
antioxidants Vitamin E, which slows down the oxidation process. Data of the chemical properties from two different time points shows that the oil is stable without a major alteration of its chemical properties. The higher stability of nahor oil is advantageous to use it in the pharmaceutical formulations.

Table 4: Physical properties of M. ferrea L. oil.

$\begin{array}{cc}\% \text { Yield } & 68.98 \% \\ \text { Sudan IV test } & +v e \\ \text { Translucence Lipid Test } & +\mathrm{ve} \\ \% \text { moisture content } & 11.86 \% \\ \text { Specific gravity } & 0.8915 \\ \text { Density }(\mathrm{g} / \mathrm{ml}) & 0.8880\end{array}$

Table 5: Chemical properties of M. ferrea L. oil.

\begin{tabular}{ccc}
\hline & Fresh oil & After 6 months \\
\hline Acid Value (mg KOH/g) & 99.7239 & 100.7847 \\
Saponification Value (mg KOH/g) & 180.9324 & 178.4238 \\
Ester Value (mg KOH/g) & 81.2085 & 88.0639 \\
Un-saponifiable matter (\%) & 2.2305 & 2.4728 \\
Iodine value (g of I/ 100g of oil) & 16.065 & 15.879 \\
Peroxide Value (meq/kg) & 10.2215 & 11.1234 \\
Vitamin E (mg/gm of lipid) & 14.99 & 13.58 \\
Cholesterol (mg/mg of lipid) & 48.17 & 47.82 \\
\hline
\end{tabular}

\section{Composition of extracted oil}

The composition of nahor oil was analyzed by TLC method. Fig. 1 represents a total of 8 well separated spots with different $R_{\mathrm{f}}$ values meaning that the sample contains a minimum of 8 different compounds. When the $\mathrm{R}_{\mathrm{f}}$ values of the sample spots were compared with the $R_{f}$ values standard substances, it became clear that the sample contains stearic acid, palmitic acid, oleic acid, linoleic acid, myristic acid, cholesterol and vitamin E, but no linolenic acid. TLC of the sample shows an additional spot at the top of the solvent front, which means the sample may contain some other components which are having different $R_{f}$ values than the standards used.

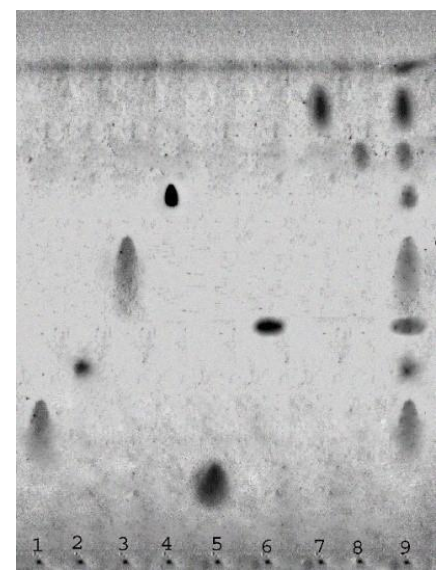

Fig. 1: TLC of M. ferrea L. seed oil. 1=stearic acid, $2=$ palmitic acid, $3=$ oleic acid, 4=linoleic acid, 5=linolenic acid, 6= Myristic acid, 7=cholesterol, $8=$ vitamin $\mathrm{E}, 9=$ M. ferrea $\mathrm{L}$. seed oil.

The quantitative analysis of fatty acid composition in nahor oil was performed using LC-MS anddata are presented in Table 6. The content (\%) of the various components was calculated by comparing the peak heights of the components. In
Fig. 2, the combined height of the peaks was considered as $100 \%$, and comparing the individual peak heights with the combined value, the quantity of fatty acid components were calculated. The peaks, which are given by the fragments of the fatty acids, were neglected in the calculation process. LC-MS study confirms that the nahor oil is composed of oleic acid (58.12\%), linoleic acid $(12.64 \%)$, stearic acid (13.45), palmitic (9.76\%), myristic acid $(2.72 \%)$ and arachidic acid $(3.14 \%)$. The content of nahor oil is very similar with the other USP grade oils (Table 2 ).

Table 6: Fatty acid composition of $M$. ferrea L. seed oil.

\begin{tabular}{cc}
\hline Fatty acids & Relative percentage (\%) \\
\hline Myristic acid (C14: 0) & 2.72 \\
Palmitic acid (C16: 0) & 9.76 \\
Linoleic acid (C18: 2) & 12.64 \\
Oleic acid (C18: 1) & 58.12 \\
Stearic acid (C18: 0) & 13.45 \\
Arachidic acid (C20: 0) & 3.14 \\
\hline
\end{tabular}

\section{Acute toxicity study of extracted oil}

Acute toxicity study of nahor seed oil was carried out in rat model with oral administration at $5 \mathrm{mg} / \mathrm{kg}, 50 \mathrm{mg} / \mathrm{kg}, 300$ $\mathrm{mg} / \mathrm{kg}$ and $2000 \mathrm{mg} / \mathrm{kg}$ body weight. There are no significant changes in the body weights $(\mathrm{P}<0.0001)$ among the treated animal groups. Students $t$-test shows that the body weight changes of the individual test group compared to the control group is insignificant $(\mathrm{P}<0.0001)$ (Table 7).

Table 7: Body weight of control and drug treated animals

\begin{tabular}{|c|c|c|c|}
\hline & Control & $5 \mathrm{mg} / \mathrm{kg}$ & $50 \mathrm{mg} / \mathrm{kg}$ \\
\hline Initial & $130.33 \pm 0.882$ & $140.67 \pm 1.764 * * *$ & $120.67 \pm 1.453^{* * *} *$ \\
\hline Day 3 & $130.67 \pm 0.882$ & $141.33 \pm 2.028 * * *$ & $121.00 \pm 1.155^{* * * *}$ \\
\hline Day 7 & $131.00 \pm 0.577$ & $141.67 \pm 1.764 * * *$ & $121.33 \pm 0.882 * * *$ \\
\hline Day 10 & $131.33 \pm 0.333$ & $142.00 \pm 1.732 * * *$ & $121.67 \pm 0.667 * * *$ \\
\hline \multirow[t]{2}{*}{ Day 14} & $131.67 \pm 0.333$ & $141.67 \pm 1.202 * * *$ & $122.00 \pm 0.577 * * *$ \\
\hline & & $300 \mathrm{mg} / \mathrm{kg}$ & $2000 \mathrm{mg} / \mathrm{kg}$ \\
\hline Initial & & $119.67 \pm 0.882 * * *$ & $121.33 \pm 1.202 * * *$ \\
\hline Day 3 & & $120.00 \pm 0.577 * * *$ & $121.67 \pm 0.882 * * *$ \\
\hline Day 7 & & $120.33 \pm 0.667 * * *$ & $122.00 \pm 1.000 * * *$ \\
\hline Day 10 & & $120.67 \pm 0.333^{* * *} *$ & $122.33 \pm 0.667 * * *$ \\
\hline Day 14 & & $121.00 \pm 0.577 * * *$ & $122.67 \pm 0.667 * * *$ \\
\hline
\end{tabular}

Values are expressed as the mean \pm S.E.M. $(n=3)$; Statistical significance $(\mathrm{P})$ calculated by one-way ANOVA. $* * * \mathrm{P}<0.0001$, NS - non-significant calculated by comparing treated group with the control group.

No mortality of test animals among any of the groups was seen. No sign of toxicity (changes on skin and fur integrity, eye color, mucus membrane, behavior, tremors, salivation, diarrhea, sleep, coma and death) was seen in any rat throughout the study (Halim et al., 2011).

\section{Characterization of the NLC formulation}

The average particle size of the NLC formulation was found to be $266.03 \pm 6.67 \mathrm{~nm}$ and the zeta potential was found to be $-34.06 \pm 0.473$. The polydispersity index (PDI) of the formulation was found as $0.313 \pm 0.098$. The results show that nano sized NLC formulations were obtained within a very narrow particle size range. Zeta potential suggests that the surface charges of the NLC particles are negative in nature and have good storage stability. 


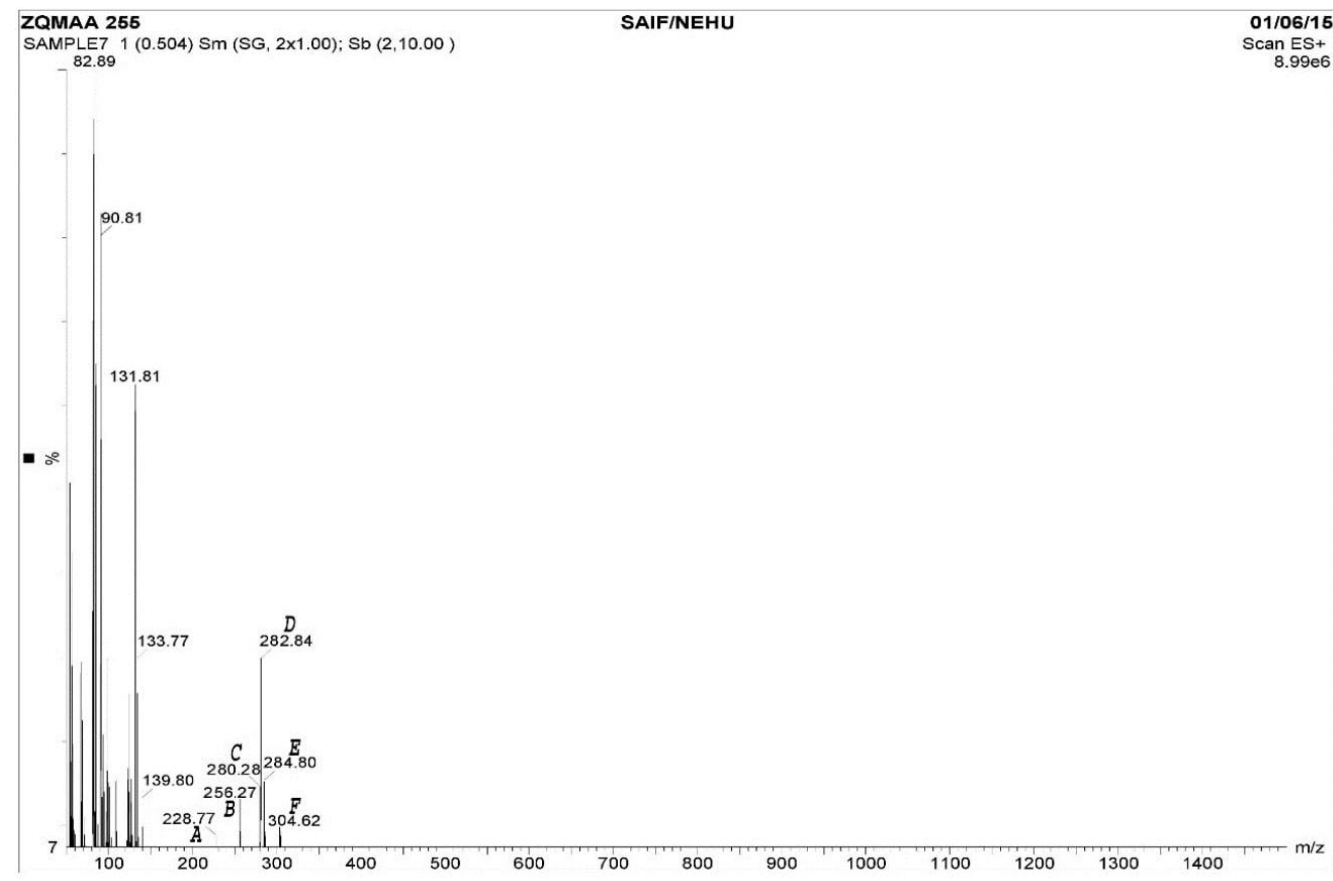

Fig. 2: LC-MS study report of M. ferrea L. seed oil. ( $\mathrm{A}=$ Myristic acid, $\mathrm{B}=$ Palmitic acid, $\mathrm{C}=$ Linoleic acid, $\mathrm{D}=$ Oleic acid, $\mathrm{E}=$ Stearic acid, $\mathrm{F}=$ Arachidic acid).

Size Distribution by Number

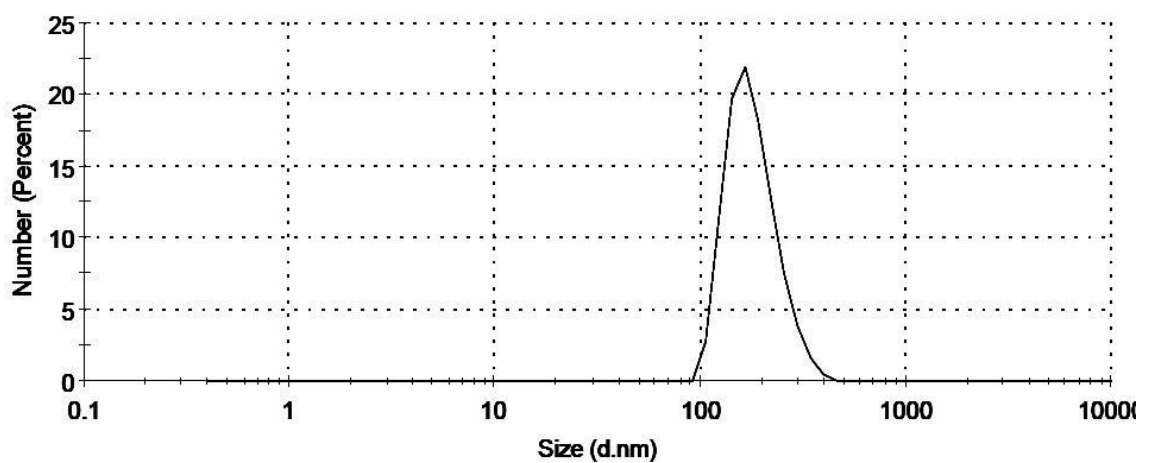

Fig.3: Particle size distribution of the NLC formulation.

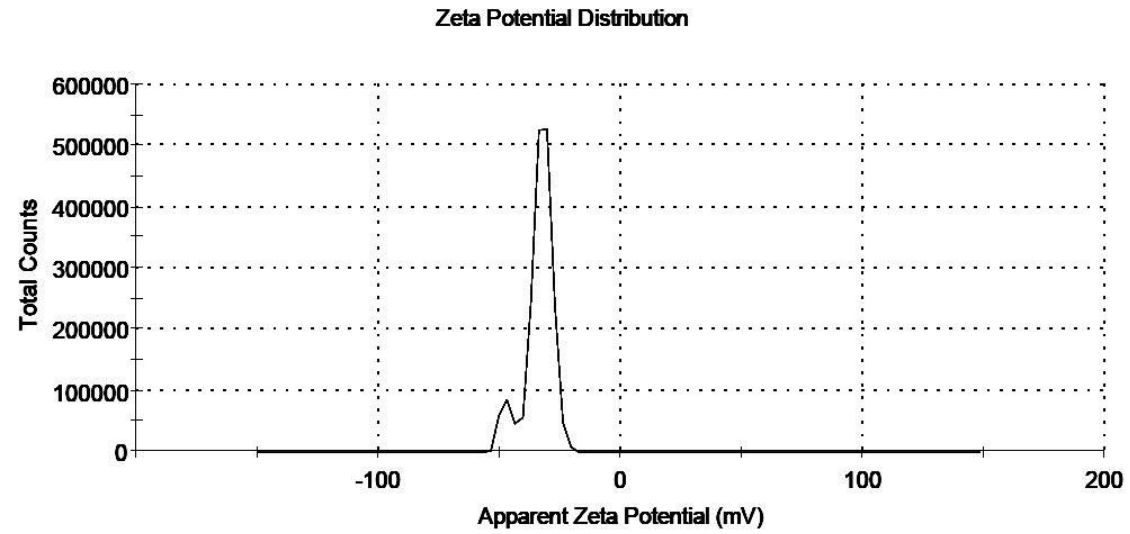

Fig. 4: Zeta potential of the NLC formulation. 

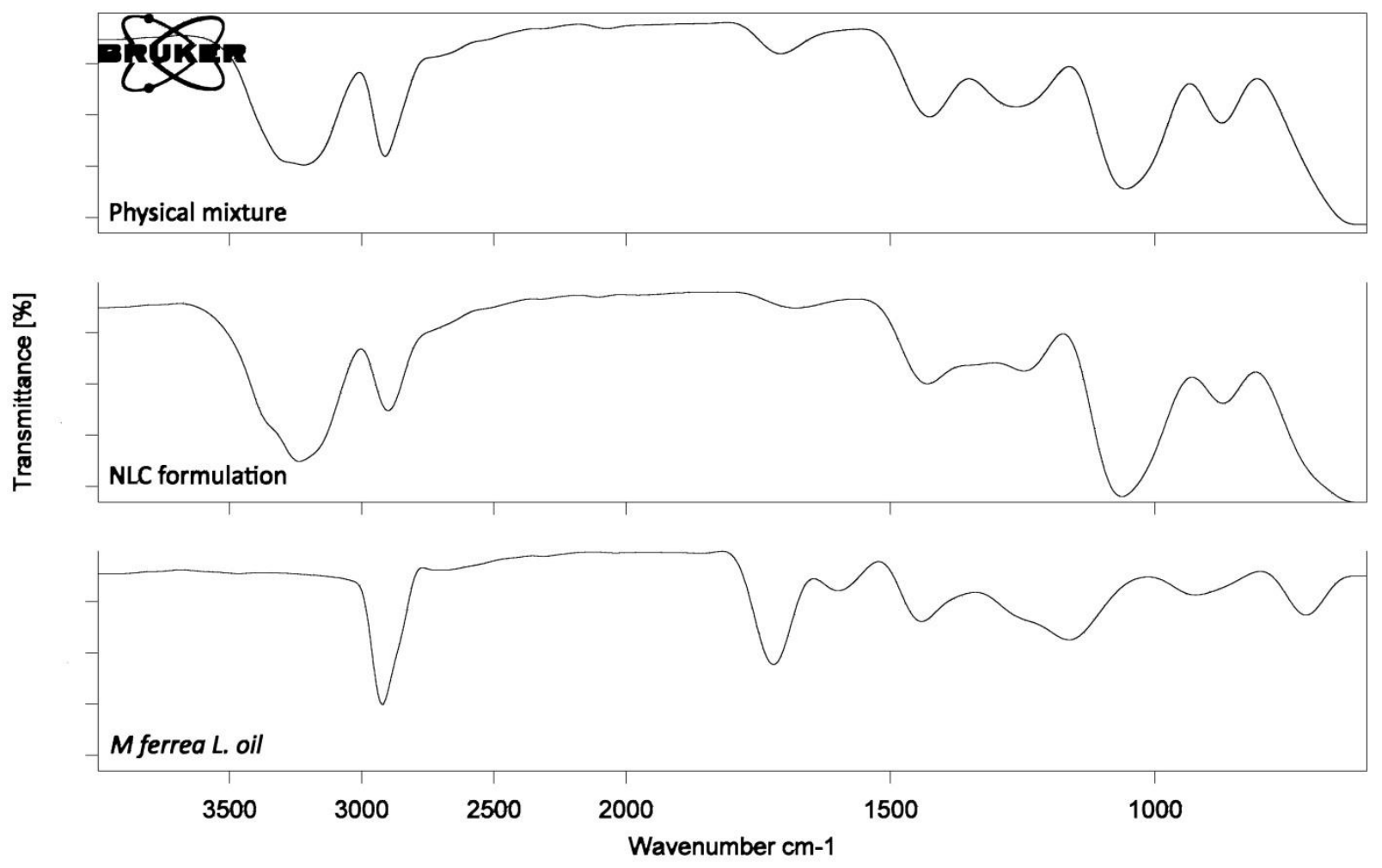

Fig. 5: IR spectrum of the physical mixture of the components and the lyophilized NLC formulation.

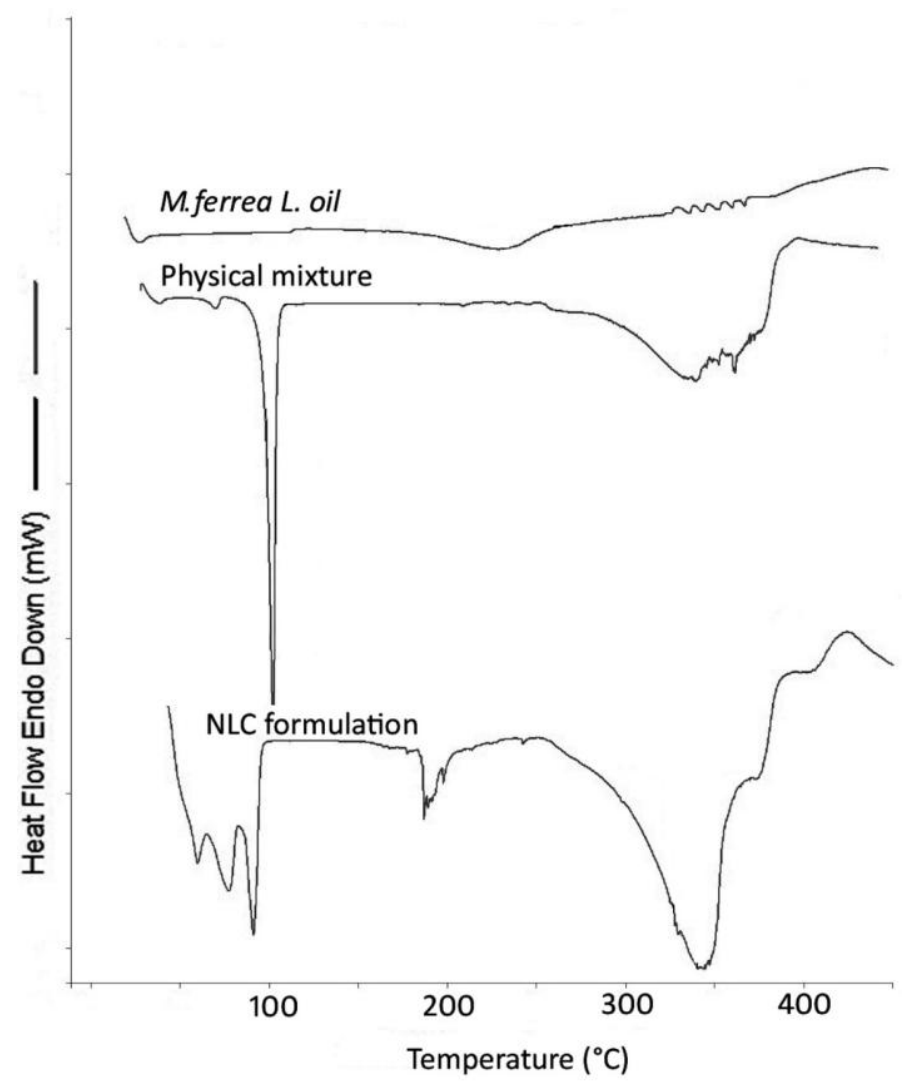

Fig. 6: DSC thermogram of NLC formulation and its physical mixtures. 


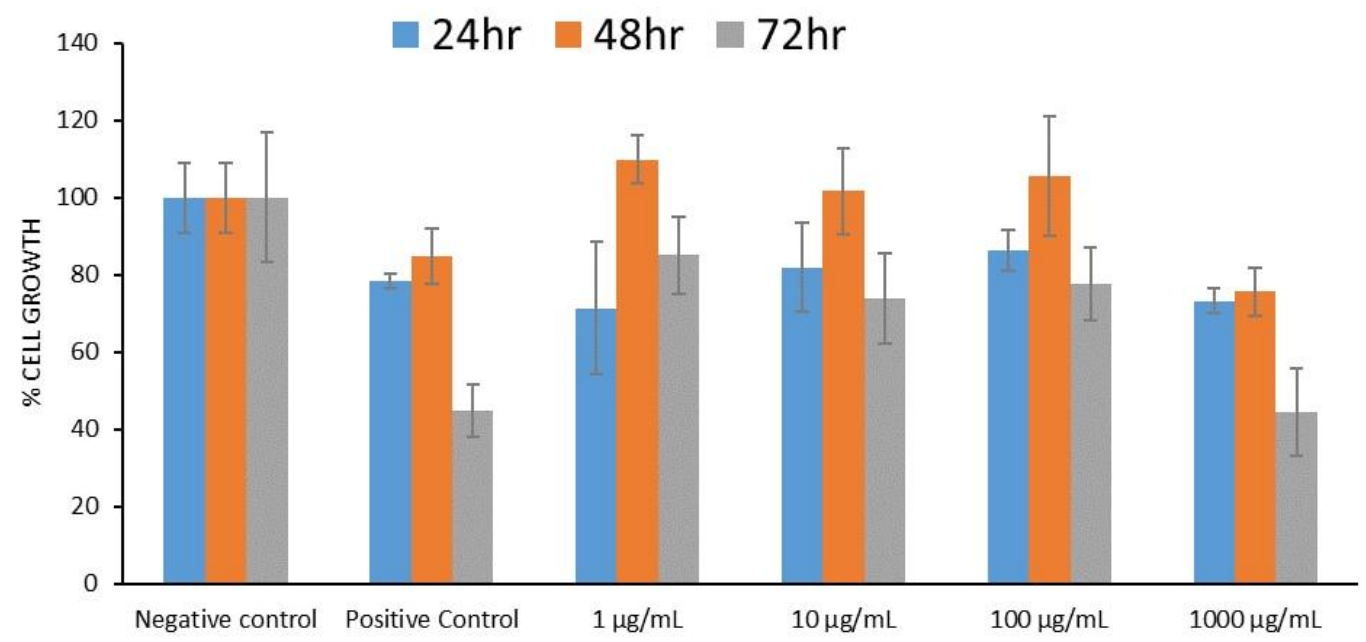

Fig. 7: Graphical presentation of the Cytotoxicity of NLC formulation on bEnd.3 cell.

\section{Compatibility study of the M. ferrea L. oil with other NLC components}

IR spectrum of behenyl alcohol, M. ferrea L. seed oil, pluronic F68, sorbitol, aphysical mixture of all the components and the NLC formulation was obtained. In the formulation as well as in the physical mixture, the major peaks of the individual components can be seen (Table 8). There is no evidence of any additional peaks appearing in the IR spectrum of the formulation as well as in the physical mixture. This phenomenon explains that all the components are compatible with one another, as if there was any incompatibility, some additional peaks might have appeared.

Table 8: Interpretation of the FTIR spectrum of physical mixture and NLC formulation.

\begin{tabular}{ccc}
\hline & Standard $\left(\mathbf{c m}^{-1}\right)$ & Peaks $\left.\mathbf{c m}^{-1}\right)$ \\
\hline $\mathrm{O}-\mathrm{H}$ & $3600-3200$ & 3230.94 \\
$\mathrm{CH}_{3}$ or $\mathrm{CH}_{2}$ & $2960-2850$ & 2891.87 \\
$\mathrm{RCOH}$ & $1750-1660$ & 1669.37 \\
$\mathrm{CH}_{3}$ or $\mathrm{CH}_{2}$ & $1470-1430$ & 1439.19 \\
$\mathrm{O}-\mathrm{H}$ & $1410-1260$ & 1268.56 \\
$\mathrm{C}-\mathrm{OH}$ & $1150-1040$ & 1076.51 \\
\hline
\end{tabular}

On comparing the DSC thermograms of the physical mixture and the lyophilized NLC formulation, it is clear that both contain the same endothermic peaks. In the thermogram of physical mixture, the peaks are more prominent and sharper than that of the formulation thermogram. This is because, in the formulation, some components get covered, entrapped by other components, which is not possible in the case of the physical mixture. There were no additional peaks appearing in the DSC thermogram of the NLC formulation than physical mixtures of all ingredients (Balestrieri et al., 1996). The absence of any exothermic peaks in the physical mixture or in the formulation thermogram means that there is no chemical reaction occurring between the components (Laszcz et al., 2007). All these study results confirm that there is no incompatibility between the excipients used in the NLC formulation (Mallik et al., 2011).

\section{Cytotoxicity study of NLC formulation}

MTT assay results indicate that the NLC formulation is nontoxic up to a dose level of $100 \mu \mathrm{g} / \mathrm{ml}$. The $1000 \mu \mathrm{g} / \mathrm{ml}$ dose shows little toxicity till $48 \mathrm{~h}$ and then it shows similar toxicity with DMSO solution. It is clear that at $48 \mathrm{~h}$ of the study, there is a better growth of the cells at all concentrations of the formulation, which gradually decreases at $72 \mathrm{~h} .80 \%$ of the cell remains alive at a dose level of $100 \mu \mathrm{g} / \mathrm{ml}$ after $72 \mathrm{~h}$. This study indicates that the NLC formulation is nontoxic to bEnd.3 cells at a dose level of $100 \mu \mathrm{g} / \mathrm{ml}$.

\section{CONCLUSION}

This study reports the successful extraction and evaluation of $M$. ferrea L. seed oil as pharmaceutical excipient. The TLC and LC-MS study suggest the oil is composed of fatty acids similar to any USP grade oil. The acute toxicity study and MTT assay suggest the safety profile of the nahor oil at cellular level in the living system. DSC and FT-IR study confirm no chemical interaction with the general components of the lipid nanoparticles. This work provides a new dimension to $M$. ferrea L. seed oil for its effective use in the pharmaceutical nanoformulation.

\section{ACKNOWLEDGEMENT}

Financial support and sponsorship: The present work is sponsored by DBT, New Delhi under Grant No. BT/504/NE/ TBP/2013.

Conflict of Interests: There are no conflicts of interest.

\section{REFERENCES}

Angius F, Floris A. Liposomes and MTT cell viability assay: An incompatible affair. Toxicol Vitr. 2015;29(2):314-319.

Arunachalam A, Khan ML, Singh ND. Germination, growth and biomass accumulation as influenced by seed size in Mesua ferrea $\mathrm{L}$. 
Turk J Botany. 2003;27(5):343-348.

Asha V. Phytochemical Investigations, Extraction and Thin Layer Chromatography of Acorus Calamus Linn. 2015;3(4):18-22.

Bahadur S, Roy A, Chanda R, Choudhury A. Natural Excipient

Development: Need and Future. Pharm Res. 2014; 4(1): 2212-2231.

Bala KR, Seshadri TR. Isolation and synthesis of some coumarin components of Mesua ferrea L. seed oil. Phytochemistry. 1971;10(5):1131-1134.

Baldrick P. Pharmaceutical excipient development: the need for preclinical guidance. Regul Toxicol Pharmacol. 2000;32(2):210-218.

Balestrieri F, Magri AD, Magri AL, Marini D, Sacchini A. Application of differential scanning calorimetry to the study of drugexcipient compatibility. Thermochim Acta. 1996;285(2):337-345.

Bandaranayake WM, Selliah SS, Sultanbawa MUS, Games DE. Xanthones and 4-phenylcoumarins of Mesua thwaitesii. Phytochemistry. 1975;14(1):265-269.

Chanda S, Rakholiya K, Parekh J. Indian medicinal herb: Antimicrobial efficacy of Mesua ferrea L. seed extracted in different solvents against infection causing pathogenic strains. J Acute Dis. 2013;2(4):277-281.

Chaudhari SP, Patil PS. Pharmaceutical Excipients : A review. Int J Adv Pharmacy, Biol Chem. 2012;1(1):21-34.

Daksha A, Jaywant P, Bhagyashree C, Subodh P. Estimation of sterols content in edible oil and ghee samples. Int J Pharm Sci Rev Res. 2010;5(1):135-137.

Fan H, Liu G, Huang Y, Li Y, Xia Q. Development of a nanostructured lipid carrier formulation for increasing photo-stability and water solubility of Phenylethyl Resorcinol. Appl Surf Sci. 2014;288:193200.

Gopalakrishnan. Anti-inflammatory and C.N.S. depressant activities of xanthones from Calophyllum inophyllum and Mesua ferrea $\mathrm{L}$. Indian J. Pharmacol. 1980; 12(3):181-191.

Halim SZ, Abdullah NR, Afzan A, Rashid BAA, Jantan I, Ismail Z. Acute toxicity study of Carica papaya leaf extract in Sprague Dawley rats. J Med Plants Res. 2011;5(xx):1867-1872.

Hilditch TP. Industrial Oil and Fat Products. Nature. John Wiley \& Sons; USA; 1946.

Jalalpure SS, Mandavkar YD, Khalure PR, Shinde GS, Shelar PA, Shah AS. Antiarthritic activity of various extracts of Mesua ferrea Linn. seed. J Ethnopharmacol. 2011;138(3):700-704.

Labuschagne $\mathrm{M}$ t., Hugo A. Oil Content and Fatty Acid Composition of Cactus Pear Seed Compared with Cotton and Grape Seed. J Food Biochem. 2010;34(1):93-100.

Lakshminarayana G, Paulose MM, Kumari BN. Characteristics and composition of newer varieties of indian castor seed and oil. J Am Oil Chem Soc. 1984;61(12):1871-1872.

Łaszcz M, Kosmacińska B, Korczak K. Study on compatibility of imatinib mesylate with pharmaceutical excipients. J Therm Anal Calorim. 2007;88(2):305-310.

Mahale S, Goswami-Giri A. Composition and Characterization of Refined Oil Compared with Its Crude Oil from Waste Obtained from Mangifera indica. Asia J Res Chem. 2011; 4(9): 1415-1419.

Makchuchi S, Ithara A, Tewtraku S. Antioxidant and nitric oxide inhibition activities of Thai medicinal plants. J Med Assoc Thail. 2010; 93 (SUPPL 7).

Mallik S, Kshirsagar MD, Saini V. Studies on physical/ chemical compatibility between synthetic and herbal drugs with various pharmaceutical excipients. Der Pharm Lett. 2011; 3(5): 173-178.

Mamoci E, Cavoski I, Simeone V, Mondelli D, Al-Bitar L, Caboni P. Chemical composition and in vitro activity of plant extracts from Ferula communis and Dittrichia viscosa against postharvest fungi. Molecules. 2011;16(3):2609-2625.

Van Meerloo J, Kaspers GJL, Cloos J. Cell sensitivity assays: the MTT assay. Methods Mol Biol. 2011;731:237-245.

Nkafamiya II, Maina HM, Osemeahon SA, Modibbo UU. Percentage oil yield and physiochemical properties of different groundnut species (Arachis hypogaea ). African J Food Sci. 2010;4(7):418-21.
Nour AH, Elhussein SA, Osman NA. Characterization and chemical composition of the fixed oil of fourteen basil (Ocimum basilicum L.) accessions grown in Sudan. Int J Chem Technol. 2010;2(3):113-119.

Nzikou J, Kimbonguila A, Matos L. Extraction and Characteristics of Seed Kernel Oil from Mango (Mangifera indica). Res J Environ Earth Sci. 2010;2(1):31-35.

De Peña DG, Anguiano R GL, Arredondo JJM. Modification of the method 1 AOAC (CB-method) for the detection of aflatoxins. Bull Environ Contam Toxicol. 1992;49(4):485-489.

Rabasco Alvarez AM, González Rodríguez ML. Lipids in pharmaceutical and cosmetic preparations. Grasas y Aceites. 2000;51(12):74-96.

Rai LK, Prasad P, Sharma E. Conservation threats to some important medicinal plants of the Sikkim Himalaya. Biol Conserv. 2000;93(1):27-33.

Rasheed NMA, Gupta VC. Standardization of a compound Unani herbal formulation "Qurs-e-Luk" with modern techniques. Pharmacognosy Res. 2010;2(4):237-241.

Rutkowski M, Grzegorczyk K. Modifications of spectrophotometric methods for antioxidative vitamins determination convenient in analytic practice. ACTA Acta Sci Pol, Technol Aliment. 2007;6(3):17-28.

Sasidharan S, Chen Y, Saravanan D, Sundram KM, Yoga Latha L. Extraction, isolation and characterization of bioactive compounds from plants' extracts. African J Tradit Complement Altern Med. 2011;8(1):110 .

Shahzad T, Anjum FM, Pasha I, Saeed F. Characterization of Different Groundnut Varieties Grown in Pakistan. Pakistan J Food Sci. 2011;21(44):52-55.

Shete H, Patravale V. Long chain lipid based tamoxifen NLC. Part I: Preformulation studies, formulation development and physicochemical characterization. Int J Pharm. 2013;454(1):573-583.

Tamjidi F, Shahedi M, Varshosaz J, Nasirpour A. Design and characterization of astaxanthin-loaded nanostructured lipid carriers. Innov Food Sci Emerg Technol. 2014;26:366-374.

Tita B, Ledeti I, Bandur G, Tita D. Compatibility study between indomethacin and excipients in their physical mixtures. $\mathrm{J}$ Therm Anal Calorim. 2014;118(2):1293-1304.

Tsai MJ, Wu PC, Huang Y Bin, Chang JS. Baicalein loaded in tocol nanostructured lipid carriers (tocol NLCs) for enhanced stability and brain targeting. Int J Pharm. 2012;423(2):461-470.

Tunaru S, Althoff TF, Nusing RM, Diener M, Offermanns S. Castor oil induces laxation and uterus contraction via ricinoleic acid activating prostaglandin EP3 receptors. Proc Natl Acad Sci U S A. 2012;109(23):9179-9184.

Udayabhanu J, Kaminidevi S, Thangavelu T. A study on acute toxicity of methanolic extract of Mesua ferrea $\mathrm{L}$. in Swiss albino mice. Asian J Pharm Clin Res. 2014;7(3):66-68.

Virendrakumar SN, Himanshu S, Vipul P, Girish J. Impact of formulation ingredients on quality of the parenteral products. 2015;4(3):468-482.

Were BA, Onkware AO, Gudu S, Welander M, Carlsson AS. Seed oil content and fatty acid composition in East African sesame (Sesamum indicum L.) accessions evaluated over 3 years. F Crop Res. 2006;97(2-3):254-260.

How to cite this article:

Chakraborty T, Das MK. Oil of Mesua ferrea L. Seed as a Promising Pharmaceutical Excipient in Lipid Based Nanoformulation. J App Pharm Sci, 2017; 7 (07): 133-141. 